\title{
The determinants of corporate liquidity in the Netherlands
}

Citation for published version (APA):

Bruinshoofd, W. A., \& Kool, C. J. M. (2002). The determinants of corporate liquidity in the Netherlands. METEOR, Maastricht University School of Business and Economics. METEOR Research Memorandum No. 013 https://doi.org/10.26481/umamet.2002013

Document status and date:

Published: 01/01/2002

DOI:

10.26481/umamet.2002013

Document Version:

Publisher's PDF, also known as Version of record

\section{Please check the document version of this publication:}

- A submitted manuscript is the version of the article upon submission and before peer-review. There can be important differences between the submitted version and the official published version of record.

People interested in the research are advised to contact the author for the final version of the publication, or visit the DOI to the publisher's website.

- The final author version and the galley proof are versions of the publication after peer review.

- The final published version features the final layout of the paper including the volume, issue and page numbers.

Link to publication

\footnotetext{
General rights rights.

- You may freely distribute the URL identifying the publication in the public portal. please follow below link for the End User Agreement:

www.umlib.nl/taverne-license

Take down policy

If you believe that this document breaches copyright please contact us at:

repository@maastrichtuniversity.nl

providing details and we will investigate your claim.
}

Copyright and moral rights for the publications made accessible in the public portal are retained by the authors and/or other copyright owners and it is a condition of accessing publications that users recognise and abide by the legal requirements associated with these

- Users may download and print one copy of any publication from the public portal for the purpose of private study or research.

- You may not further distribute the material or use it for any profit-making activity or commercial gain

If the publication is distributed under the terms of Article $25 \mathrm{fa}$ of the Dutch Copyright Act, indicated by the "Taverne" license above, 


\title{
The Determinants of Corporate Liquidity in the Netherlands*
}

\author{
Allard Bruinshoofd** \\ Clemens Kool \\ Department of Economics - Maastricht University, Maastricht, the Netherlands.
}

April 2002

\begin{abstract}
We investigate the driving forces of corporate liquidity for a balanced panel of large Dutch nonfinancial firms during the period 1986-1997 using an error-correction framework. This framework allows a crucial distinction between short-run and long-run determinants of corporate liquidity. We conclude from our empirical estimates that long-run corporate liquidity targets exist and are based on a small number of firm characteristics. In the short run liquidity responds passively to exogenous shocks. The latter phenomenon is consistent both with buffer stock behaviour and pecking order theory. Passive liquidity behaviour does not extend to the long run, however. On average eighty percent of deviations from target is eliminated within one year. Overall, we conclude that the corporate liquidity ratio is an actively managed financial ratio and does not passively adjust to financial decisions taken elsewhere in the firm. Based on long run evidence, a pecking order theory of corporate liquidity holdings must be rejected.
\end{abstract}

Keywords: Corporate liquidity demand, precautionary liquidity, static trade-off JEL Classification: G3, E41

\footnotetext{
We thank Jaap Bos, Bertrand Candelon, Leo de Haan, Alain Hecq, Wilko Letterie, Michiel van Leuvensteijn, Jean-Pierre Urbain, participants of the CAED 1999, the German Finance Association 2001, the NAKE Research Day 1999 and seminar participants at Maastricht University and the National University of Singapore for helpful comments. The research is supported by a grant from the Maastricht Research School of Economics of Technology and Organizations (METEOR) and was partially carried out at the Center for Research of economic Micro-data (Cerem) of Statistics Netherlands. The views expressed are those of the authors and do not necessarily reflect policies of Statistics Netherlands. In addition, the usual disclaimer applies.

** Postal address: Department of Economics - Maastricht University, P.O.Box 616, 6200 MD Maastricht, the Netherlands. Phone: (0)43 388 2685. Fax: (0)43 388 4864. E-mail: a.bruinshoofd@algec.unimaas.nl.
} 


\section{Introduction}

Firms structurally invest in liquid assets. Opler, Pinkowitz, Stulz and Williamson (1999), for example, document that for their sample of publicly traded US firms the liquidity ratio amounts to around five percent during the period 1971-1994. Kim, Mauer and Sherman (1998) report an average liquidity ratio of roughly eight percent for US industrial firms in the 1975-1994 period. Nevertheless, the value of corporate liquidity is an unresolved question in the theory of finance (eg. Brealey and Myers, 1996).

The purpose of this paper is to build a synthesis of two opposing theoretical approaches to corporate liquidity motives and to examine their relative contribution in explaining actual corporate liquidity holdings in the Netherlands. Specifically, we are interested in the issue of whether firms actively pursue implicit liquidity targets or whether liquidity holdings are deemed unimportant and therefore passively adjust to (more important) financial decisions taken elsewhere in the firm.

The empirical literature so far on this topic is sparse - mainly due to a lack of highquality firm-level data - and it does not provide clear-cut answers to this point. Kim et al. (1998) provide empirical support for the theoretical "tradeoff between low return on liquid assets and the benefit of minimizing the need for costly external financing". Opler et al. (1999) stress a distinction between active formulation and pursuit of liquidity targets on the one hand and a more passive stance on the other. According to this latter view, liquidity follows from the pursuit of a net debt target or pecking order behaviour in finance. For the Netherlands, De Haan, Koedijk and De Vrijer (1994) find evidence for buffer stock determinants of corporate liquidity using qualitative survey data.

In this paper, we extend and improve on the currently available empirical literature in two ways. First, we exploit a new firm-level data set for large non-financial firms in the Netherlands. Since the data consistently cover the twelve year period 1986-1997 we are able not only to investigate cross-sectional characteristics of liquidity holdings but to include a time dimension as well. This latter point immediately brings us to the second innovation. Contrary to the existing literature on firm liquidity holdings we propose a clear-cut distinction between the determination of corporate liquidity in the short run and the long run. In our view, the possible existence of corporate liquidity targets can only be judged by looking at long-run characteristics. We argue that short run cash dynamics may have a 
dominantly passive character both with and without clear-cut targets. Without a target, a firm's liquidity both in the short run and the long run is determined by its cash flows as forcefully argued by the pecking order theory. However, even with a target a firm's short-run liquidity dynamics may depend on its current performance through the buffer-stock approach as introduced by Carr and Darby (1981). Consequently, short-run evidence is unable to distinguish between the two hypotheses due to observational equivalence. Long-run liquidity behaviour will more clearly show whether implicitly formulated liquidity targets or ranges are actively pursued.

Therefore, we analyse liquidity holdings in an error correction framework to integrate the different views on liquidity holdings in a testable way. Estimation results are supportive of our conjectures. The main thrust of our estimation results is that a target adjustment framework for corporate liquidity holdings may feature short run dynamics that are in line both with pecking order behaviour and buffer stock behaviour. Long run pecking order determination of corporate liquidity, however, is rejected by the existence of optimal liquidity ratios that are motivated by static trade off arguments. As a corollary, we find reversion to firm-specific liquidity targets at a rate of eighty percent per year. This is in sharp contrast with the adjustment speed of money demand in aggregate data, usually found in the literature. Our results point to the existence of aggregation problems.

The plan of the paper is as follows. In the next section we summarize the theoretical determinants of corporate liquidity. We pay specific attention to the role of asymmetric information problems in the determination of the precautionary demand for liquidity. Also, we elaborate on the distinction in liquidity determination between the short and long run. In section 3 we present and characterize the data and construct the variables used in our empirical analysis. In section 4 we present our estimation results using an error correction framework and in section 5 we summarize and conclude.

\section{The determinants of corporate liquidity}

In this section, we start with a discussion of the standard determinants of corporate holdings of liquid assets. In this respect, we distinguish between the presence of transaction costs, opportunity costs and informational asymmetries. Together these factors yield an optimum liquidity level or ratio, which we label the static trade off level, following Opler et al. (1999). 
Subsequently, we turn to another branch of the literature, where liquidity holdings are assumed to adjust passively to other financial decisions taken in the firm. This may reflect pecking order behaviour and the absence of any actively pursued liquidity target, but also it may reflect the buffer stock property of liquidity in the short-run only and a longer-term return to a target.

\section{Transaction and opportunity costs}

The presence of positive transaction costs alone is sufficient to create a positive demand for liquidity. With zero opportunity costs, optimal holdings of corporate liquidity are unbounded. When opportunity costs are positive, however, firms will economize on liquidity holdings. Transaction and opportunity costs together then determine a positive and finite optimal amount of corporate liquidity holdings. In applied work, often used variables to capture the transaction motive are sales (in an inventory approach) or assets (in a Keynesian or portfolio framework). A benchmark interest rate then is generally assumed to account for the opportunity cost of holding liquid assets. More generally, all relevant substitutes for liquidity like f.i. net working capital and minority holdings in other firms may need to be taken into account.

In addition, a precautionary demand for money may exist. One argument is the expectation of future investment opportunities. A second argument concerns uncertainty regarding future cash inflows and outflows. In particular, firms characterised by a more volatile cash flow history will desire a larger precautionary stock of liquidity. Third, firms with large amounts of short term debt possibly face a larger degree of refinancing uncertainty (Holmström and Tirole, 2000). This last factor is closely related to the informational motives for holding liquidity. The relation stems from the fact that refinancing becomes more uncertain when there is a possibility that future debt rollovers are denied. We turn to this issue now.

\section{Informational problems}

According to Holmström and Tirole (1998), asymmetric information problems between firms and financial markets raise the difficulty and cost of obtaining external finance and hence 
create a (precautionary) demand for corporate liquidity. ${ }^{1}$ De Haan, Koedijk and de Vrijer (1992) find supportive evidence for this hypothesis examining Dutch corporate liquidity holdings through a survey questionnaire. We label this effect the informational cost of external finance. It can occur through firm specific characteristics, but also through sector and time specific factors.

An example of a firm-specific characteristic is the amount of leverage. In general, higher leverage increases moral hazard and thus the marginal cost of debt, see Freixas and Rochet (1997) and Hubbard (1998). With higher leverage, a firm then faces a higher degree of uncertainty regarding future access to debt financing and desires higher precautionary liquidity holdings. ${ }^{2}$ This theoretical consideration is in line with empirical findings of De Haan (1997) and Van Ees, Garretsen, De Haan and Sterken (1998) who, for a sample of Dutch firms, find that a debt-constraint augmented model of investment outperforms a neoclassical specification. Another example is the informational sensitivity of a firm's activities. Investment in research and development (R\&D), for instance, is likely to be subject to stronger asymmetries in information than investment in manufacturing plants and equipment (eg. Opler et al., 1999).

Sector and time specific factors may add to this. Investments in the ICT sector may be more sensitive to asymmetric information than investments in the manufacturing sector (cf. Chirinko and Schaller, 1995; Weigand and Audretsch, 1999). Similarly, investments in recessions may exhibit a higher informational sensitivity compared to investments in booms (cf. Calomiris, Himmelberg and Wachtel, 1994).

Another form of informational asymmetries potentially affecting liquidity holdings arises from the existence of agency problems between management and owners of a firm (cf. Grossman and Hart, 1983). Managers may value corporate liquidity higher than owners and thus desire higher liquidity targets for a number of reasons. First, management may be overly concerned with liquidation risk, whereas shareholders can more easily diversify and so reduce the impact of a single bankruptcy on their portfolio return. Shareholders therefore

\footnotetext{
Firms with the most severe information problems may also be restricted to issuing expensive short term debt instead of more favourable long term debt à la Diamond (1991a), which by itself stimulates a higher precautionary demand for liquidity (Holmström and Tirole, 2000).

2 Myers and Rajan (1998) on the other hand suggest that higher liquidity may worsen the information problem rather than cure it. In that case, the cost of external finance may increase in liquidity holdings.
} 
likely put more emphasis on profits and hence prefer lower levels of precautionary liquidity. Second, managers may be empire builders rather than profit maximisers. ${ }^{3}$ Empire builders value projects that add to the size of the firm without necessarily being profitable. As the market does not value such projects, empire builders prefer a precautionary amount of liquidity that allows them to exploit empire building investment opportunities. Third, management may also value liquidity more than shareholders do simply because it can be freely spent on perquisites, see Jensen (1986).

Therefore, corporate liquidity holdings will generally increase with managerial discretion. The costs of managerial discretion will be lower, the more a firm is subject to monitoring and the disciplining forces of the (capital) markets. To the extent that relationships with financial intermediaries induce information production and monitoring activities (cf. Diamond, 1984, 1991b), managerial discretion is limited and corporate liquidity holdings will be reduced. ${ }^{4}$ Thus we may expect that higher leverage leads to lower levels of liquidity through the monitoring channel. Moreover, strong bank relations may cause a firm to feel comfortable with lower levels of precautionary liquidity, since banks are critical providers of liquidity especially when the market develops unfavourably (eg. Saidenberg and Strahan, 1999). ${ }^{5}$

\section{Pecking order behaviour and buffer stock liquidity}

In contrast to the static trade off view on corporate liquidity demand is the view where liquidity is passively drifting along on the waves of fortune of the firm. Such a view is not directly following from the strict pecking order theory, which focuses on the passive adjustment of capital structure in general and net debt in particular (eg. Myers and Majluf,

3 Freixas and Rochet (1997, particularly pp. 125-129) consider behaviour of empire builders. Empire builders are constrained by debt contracts, which reduce free cash flow (managerial discretion) and hence limit the opportunity to invest in negative present value projects.

$4 \quad$ Other factors may impact on managerial discretion as well. Dispersed ownership, size of the firm and charter amendments may act as takeover deterrents. This lowers capital market discipline and therefore, all else equal, raises corporate liquidity holdings.

5 This argument counteracts the earlier hypothesis that higher leverage leads to higher liquidity holdings due to refinancing uncertainty (cf. Holmström and Tirole, 1997). However, we note that the monitoring and information production effects stemming from long term debt are probably larger than those stemming from short maturities (eg. Diamond, 1991a; Freixas and Rochet, 1997) so that our earlier conjecture remains unambiguous when related to short-term debt 
1984). However, it is consistent with such theory. ${ }^{6}$ In this view, firms care little about the amount of liquidity that is reported on their balance sheets. Rather, they let liquidity holdings adjust passively to discrepancies between inflows and outflows of funds. In its extreme form pecking order liquidity behaviour predicts that all expenses (investment in fixed assets and working capital, debt repayments, dividend payments, and so on) are extracted from liquid assets. All revenues (cash flow, new debt, sale of fixed assets or working capital) are added to it. De Haan (1997) presents evidence that suggests that pecking order arguments are relevant determinants of Dutch corporate capital structure adjustments.

Closely related to this concept is the theory of buffer stock liquidity. According to the latter, firms may initially choose to let their liquidity holdings absorb any shocks, while in the longer term trying to return to an optimal level of corporate liquidity. Note that buffer stock liquidity does not necessarily assume that firms are unaware of the benefits and costs of corporate liquidity. A sufficient condition is that the firm stresses other financial targets more than it does liquidity holdings. De Haan et al. (1994) find that for Dutch firms corporate liquidity holdings exhibit distinct elements of a buffer stock approach while at the same time elements of pecking order behaviour characterize capital structure adjustment.

\section{Static trade off versus buffer stock and pecking order behaviour}

The theoretical divide between the static trade off and buffer stock views on corporate liquidity is largely artificial. The difference mainly lies in the time horizon of the analysis. In particular, consider a precautionary demand for liquid balances driven by informational problems in the capital markets. According to the static trade off view on liquidity, an increase in these informational problems pushes the related (long run) precautionary demand for liquidity upwards. Dynamically, if these same informational problems at a point in time restrict access to external finance, firms run down liquidity. The important realization is that this short run behaviour is possible because of the long run target level. At the same time its 'shock absorbing' nature is exactly in line with the buffer stock view on liquidity.

The theoretical divide between the static trade off and pecking order views on corporate liquidity is nontrivial. Strict pecking order behaviour in finance implies that long run liquidity targets do not exist. Hence we can test for the role of pecking order

6 In theory, liquidity targets may also be absent if a firm has an optimal capital structure which is cast in the form of a net debt target, see Opler et al. (1999). 
determination of long run corporate liquidity levels by assessing the long run impact of sources and uses of funds. In a static trade off world, such influences have a short term character and do not influence long run targets. Under the pecking order, these influences extend to the long run. Unfortunately, the short run implications of pecking order behaviour as the driving force of corporate liquidity holdings are empirically difficult to discriminate from buffer stock behaviour. Similarly to the buffer stock view on corporate cash, namely, the pecking order implies that liquidity rises when the sources of funds exceed the uses of funds and vice versa. Hence we may - and in fact will - find short run corporate liquidity behaviour seemingly supporting the pecking order view while simultaneously long run liquidity targets are relevant and actively pursued.

\section{Data and variable definition}

\section{Data structure}

The data used for the empirical testing of our corporate liquidity holdings framework is derived from Statistics Netherlands' data on the Finances of Large Firms (SFGO) covering the period 1977-1997. The SFGO provides company specific financial information at the level of balance sheet and income statement items for all large Dutch non-financial firms. ${ }^{7}$ For the estimation of our empirical model, we prefer a balanced panel. This bypasses potential selection effects that may emerge from specific characteristics of firms entering and leaving the data within the sample period. For this reason and due to attrition, we restrict our period of analysis to 1986-1997. A balanced panel of 473 firms results, of which 197 are manufacturing firms and 182 are services firms. ${ }^{8}$

7 The size requirement for inclusion in the SFGO is a balance sheet length of at least 20 million Dutch guilders. If a part of a non-financial firm operates in the financial sector, that part - but not the firm itself is removed from the data.

$8 \quad$ Manufacturing firms are those in sectors II (Foods and goodies industries, SBI93 15, 16), III (Petrochemical industry, SBI93 23), IV (Chemical, rubber and synthetic materials producing industries, SBI93 24, 25), V (Metals, machines and transports producing industries, SBI93 27-35), VI (Other industries, SBI93 $17-$ 22, 26, 36, 37) and VII (Public utilities, SBI93 40, 41). Services firms are those in sectors IX (Wholesale and retail trade, SBI93 50-52), X (Hotel and catering industry, SBI93 55), XI (Transportation, storage and communication, SBI93 60-64) and XII (Real estate, personal property and commercial services, SBI93 70-74). The other firms are in sectors I (Agriculture, fishery and minerals, SBI93 1-14), VIII (Construction industry, SBI93 45) and XIII (Public services, education, health care and miscellaneous services, SBI93 75-93). Note that public utilities is not conventionally included in the manufacturing sector. However, in the regression analysis it appeared that the firms in this sector behaved much like manufacturing firms. 


\section{Variable definition and descriptive statistics}

Figure 1 plots the development of the Dutch corporate liquidity ratio. A few features catch the eye. First, the liquidity ratio is following a downward trend since 1987 and has declined by more than one percentage point over the sample period. ${ }^{9}$ Second, there are distinct peaks in 1987 and 1994, which correspond well enough with downturns in the economic cycle to suspect the presence of macro-economic effects on the corporate liquidity ratio. Third and last, services firms systematically have a higher liquidity ratio than manufacturing firms; at the end of the sample period it is nearly twice as high as for manufacturing firms. We will explore later on to what extent liquidity targets are formulated differently for services and manufacturing firms.

\section{Figure 1}

Mean corporate liquidity ratios (in percentages)

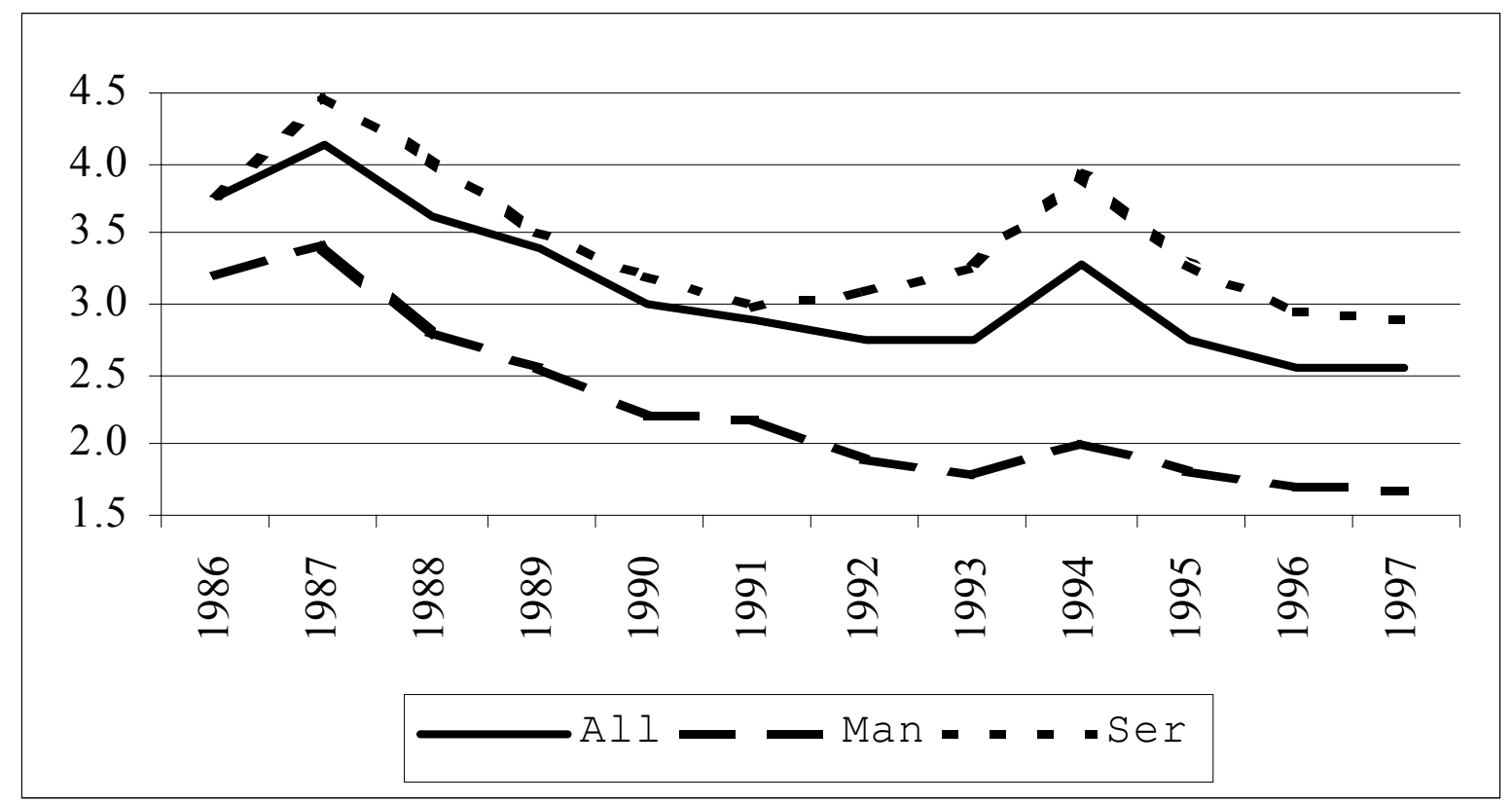

Notes: the liquidity ratio is defined as liquid assets over total assets less liquid assets where liquid assets is the sum of cash, short terms investments, term deposits and demand deposits. "All" indicates all 473 firms in the balanced panel, "Man" represents the 197 manufacturing firms and "Ser" represents the 182 services firms.

9 Noteworthy in this regard is that the national liquidity ratio had been on a rising trend since the early 1980s and was perceived as being excessively high in the late 1980s (eg. Kuipers and Boertje, 1988, De Haan et al., 1992; De Haan et al. 1994). 
For the remainder of this analysis, liquidity refers to the log of holdings of liquid assets (cash, short term investments, term deposits and demand deposits) as a fraction of total assets less liquid assets. Table 1 provides descriptive statistics on liquidity holdings, asset structure (size, assets, net working capital), liability structure (total debt and short debt) and flow of funds characteristics (investment, dividends, cash flow). We refer to the table for the exact definition of the variables. In addition to firm specific variables, we include information on share prices as an indicator of the average, economy-wide availability of external funds. The

\section{Table 1}

Descriptive statistics: 1986-1997

\begin{tabular}{|c|c|c|c|c|c|c|c|}
\hline \multicolumn{2}{|c|}{ Variable $^{1}$} & \# Obs. & Mean & $\begin{array}{c}\text { Standard } \\
\text { error }\end{array}$ & $\begin{array}{l}\text { Standard } \\
\text { deviation }\end{array}$ & Median & $\begin{array}{c}\text { Order of } \\
\text { integration }^{2}\end{array}$ \\
\hline \multicolumn{2}{|c|}{ Liquidity } & 5676 & -3.480 & 0.028 & 2.137 & -3.175 & $\mathrm{I}(1)$ \\
\hline \multicolumn{2}{|c|}{ Size } & 5676 & 11.863 & 0.018 & 1.334 & 11.565 & $\mathrm{I}(1)$ \\
\hline \multicolumn{2}{|c|}{ Assets } & 5676 & 11.974 & 0.017 & 1.306 & 11.653 & $\mathrm{I}(1)$ \\
\hline \multicolumn{2}{|c|}{ Sales } & 5676 & 1.841 & 0.019 & 1.408 & 1.515 & $\mathrm{I}(1)$ \\
\hline \multicolumn{2}{|c|}{ Net working capital } & 5676 & 0.036 & 0.003 & 0.238 & 0.035 & $\mathrm{I}(0)$ \\
\hline \multicolumn{2}{|c|}{ Near liquidity } & 5676 & 0.478 & 0.003 & 0.237 & 0.490 & $\mathrm{I}(1)$ \\
\hline \multicolumn{2}{|c|}{ Short debt } & 5676 & 0.764 & 0.003 & 0.240 & 0.828 & $\mathrm{I}(1)$ \\
\hline \multicolumn{2}{|c|}{ Total debt } & 5676 & 0.532 & 0.003 & 0.204 & 0.539 & $\mathrm{I}(1)$ \\
\hline \multicolumn{2}{|c|}{ Investment } & 5676 & 0.078 & 0.001 & 0.073 & 0.059 & $\mathrm{I}(0)$ \\
\hline \multicolumn{2}{|c|}{ Dividends } & 5676 & 0.032 & 0.001 & 0.092 & 0.003 & $\mathrm{I}(0)$ \\
\hline \multicolumn{2}{|c|}{ Cash flow } & 5676 & 0.059 & 0.002 & 0.168 & 0.072 & $\mathrm{I}(0)$ \\
\hline 1 & \multicolumn{7}{|c|}{$\begin{array}{l}\text { Liquidity is defined as the logarithm of cash and marketable securities over net assets; net assets is } \\
\text { total assets less cash and marketable securities; Size is the logarithm of net assets expressed in } 1990 \\
\text { prices; Assets is the logarithm of total assets expressed in } 1990 \text { prices; Sales is defined as the sales-to- } \\
\text { net assets ratio; Net working capital is the sum of short term claims, inventories and work in progress } \\
\text { less short term debt to net assets; Near liquidity is the ratio of short term claims, inventories and work } \\
\text { in progress to net assets; Short debt expresses short term debt as fraction of short and long term debt; } \\
\text { Total debt is defined as total debt over total assets; Investment is changes in tangible fixed assets due } \\
\text { to purchase or production over net assets; Dividends is defined as total dividend payments to net }\end{array}$} \\
\hline 2 & \multicolumn{7}{|c|}{$\begin{array}{l}\text { We use } \mathrm{I}(0) \text { and } \mathrm{I}(1) \text { to signify that a series is integrated of order zero anc } \\
\text { Harris and Tzavalis (1999) test and a } 95 \% \text { level of confidence. }\end{array}$} \\
\hline
\end{tabular}


share price used is the general index reported in the IFS of the IMF. Over the sample period share prices increased considerably. To the extent that this indicates smoother access to external funds, it may have contributed to lower precautionary liquidity holdings. ${ }^{10}$ Note that throughout the paper variable names are in italics.

\section{$4 \quad$ Estimation results}

To integrate the long-run and short-run analysis of corporate liquidity holdings, we hypothesize an error-correction specification of liquidity. In such a specification, the dynamics of liquidity are determined by various short run shocks in addition to attempts to drive the actual liquidity level to the desired long run (static trade off) level. We start, however, with an empirical investigation of the long-run determinants of corporate liquidity to arrive at measures of long run corporate liquidity targets. The two-step procedure also allows us to consider the effect of allowing for firm and/or time specific effects in these targets and their impact on restricted error correction. We elaborate on the motivation to do so later on.

\section{The determination of corporate liquidity levels}

Table 1 already contains statistical information about the long-run characteristics of the different series used. In the last column of table 1, the order of integration of the variables is indicated. For the assessment of the order of integration we evaluate the normalized least squares estimator of the autoregressive coefficient $(n)$, allowing for fixed effects ( ") and a common time trend $\left(^{*}\right)$, in $y_{i t}=\alpha_{i}+\delta_{t}+\varphi y_{i(t-1)}+\phi_{i t}$. We test $H_{0}: n=1-$ at the $95 \%$ confidence level - versus the alternative $H_{a}: n<1$. Harris and Tzavalis (1999) demonstrate that $\sqrt{N}\left(\hat{\varphi}-1+\frac{15}{2(T+2)}\right)$ weakly converges to $N\left(0, \frac{15\left(193 T^{2}-728 T+1147\right.}{112(T+2)^{3}(T-2)}\right)$. The limiting

10 Note that share prices may also contain business cycle information. If share prices go up together with the business cycle, an expected increase in macroeconomic performance may raise desired transaction balances, countering the negative effect on desired liquidity holdings produced by the increased availability of external funds. 
distribution of this test is shown to be normal for $N>100$ and $T$ small relative to $N$, conditions satisfied by our data. ${ }^{11}$

Liquidity is shown to be $I(1)$. This result implies that the long run level of liquidity is nonstationary. Consequently, the long-run determinants of liquidity must be nonstationary as well. Table 1 shows that size, near liquidity, short debt and total debt all obey this condition and therefore are potential long-run determinants of liquidity. Net working capital, investment, dividends and cash flow, however, are all I(0). A preliminary conclusion based on the statistical characteristics of these latter variables would be that they are possible driving forces of short-run liquidity dynamics, but not of long run liquidity targets. It presents indicative evidence against a strict pecking order explanation of liquidity behaviour. ${ }^{12}$

Direct estimates of long run liquidity targets result from a regression of the level of liquidity on the long run determinants of liquidity only:

$$
y_{i t}=\beta_{n}^{\prime} x_{i t}+\lambda_{t}+\eta_{i}+v_{i t}
$$

where $y$ represents the corporate liquidity ratio and $x$ stands for the vector of explanatory variables. Time and unit specific random effects are captured by $\lambda_{t}$ and $\eta_{i}$, respectively, while the remaining white noise error is indicated by $v_{i t}$.

The regression results for equation (1) are presented in table 2. Comparing the random effects (RE) estimates with the ordinary least squares (OLS) estimates first of all suggests that our results are not particularly sensitive to the estimation method used. We will discuss the full sample results first and then generalize our findings to the separate sectors. Size captures any scale effect in liquidity management. The negative parameter estimate shows that liquidity increases less than one for one with size. Total debt and short debt capture the

11 We are aware of the debate in the literature regarding the validity of unit root computation for panel data. For elaboration on this issue, see for instance the survey by Baltagi and Kao (2000). We compute unit root test statistics using the Harris and Tzavalis (1999) technique; a choice that is motivated by the small $T$ character of our panel.

12 According to the pecking order theory, flow of funds variables (like f.i. cash flow) would be the dominant short-run and long-run determinants of corporate liquidity holdings, see Opler et al. (1999). Despite its $I(0)$ character, we explored the role of cash flow as a long run determinant of corporate liquidity here. The (unreported) estimation results show that parameter estimates are negative and statistically insignificant, rejecting this hypothesis. 


\section{Table 2}

Level estimates of corporate liquidity ${ }^{1}$

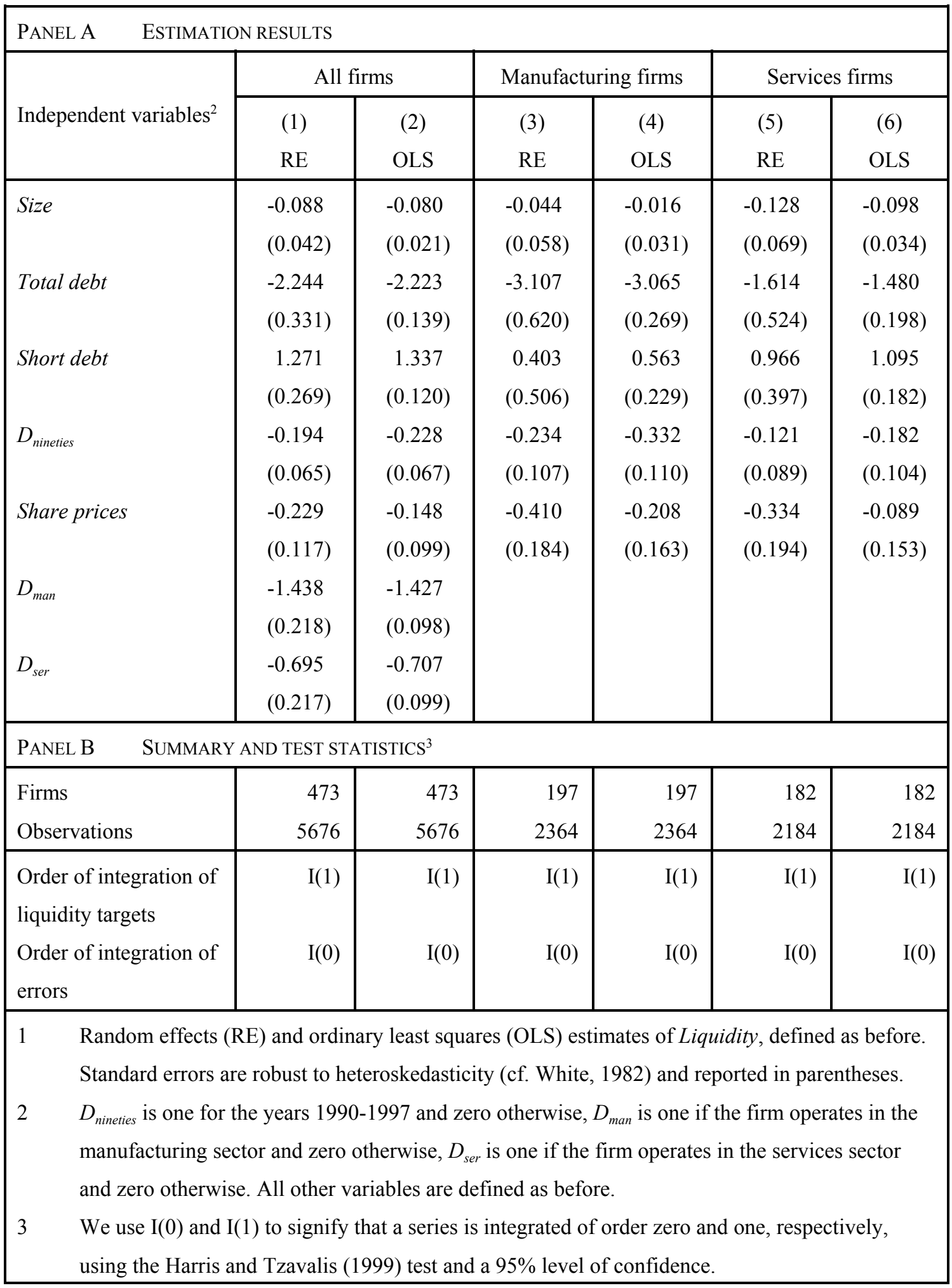


impact of leverage and debt maturity structure. Total debt carries a strong, significantly negative parameter estimate. The theoretical arguments discussed in section 2 suggest that this result captures creditors' monitoring efforts (cf. Diamond, 1991b) which may directly and indirectly reduce corporate liquidity holdings. Through the direct channel, monitoring reduces managerial discretion and hence lowers liquidity. Indirectly, monitoring may reduce information asymmetries and hence lower the risk premium on external finance, which reduces the corporate demand for precautionary liquidity. ${ }^{13}$

In the spirit of Diamond (1991a) we have included the short term debt share in total debt (short debt) to characterize the debt maturity structure. The positive parameter estimate implies that for any given level of total debt, a larger short debt (. shorter average maturity) increases liquidity. This effect lies probably closest to the refinancing uncertainty that we conjectured to impact on the informational cost of external finance. ${ }^{14}$

The macroeconomic environment plays an important role in corporate liquidity determination through share prices. Share prices relate negatively to liquidity. As we conjectured before, this might be explained by the reduced need for precautionary liquidity that stems from an economic environment where access to credit is relatively easy. ${ }^{15}$

The construction of the dummy variables $D_{\text {man }}, D_{\text {ser }}$ and $D_{\text {nineties }}$ is motivated by initial estimates, which included dummies for each year and each sector. The intercept estimates for different manufacturing sectors were statistically insignificantly different from each other. The same holds for the various services sectors. Collectively, manufacturing firms show significantly lower intercept estimates than services firms. This pattern is captured by the

The informational cost of external finance view would predict that higher leverage would increase the risk premium on external finance, rather than decrease it, since higher leverage implies that firms are closer to their debt capacity. The empirical results suggest that the negative monitoring effect on this risk premium outweighs the informational cost of external finance effect. Two additional explanations suggest that higher leverage ratios indicate better historical access to debt and hence a reduced precautionary liquidity motive and/or self-restraining management that prefers not to concern its creditors with high levels of liquidity when leverage is high as well (cf. Myers and Rajan, 1998).

14 Note that increases in the level of short and long term debt alike have a negative impact on liquidity holdings. For an increase in long term debt, through a higher total debt and lower short debt, this effect is unambiguous. For an increase in short term debt, via a negative effect through total debt and a positive effect through short debt, this result holds at sample means and given the parameter estimates in table 2 .

15 However, one can also suspect that firms react opportunistically to such circumstances by raising funds for future use, hence adding to liquidity holdings. We discard this short term behaviour in the determination of long run liquidity targets. Unreported results furthermore show that the lending rate has only a small and statistically insignificant coefficient, in line with empirical findings presented by De Haan et al. (1992). 
dummies $D_{\text {man }}$ and $D_{\text {ser }}{ }^{16}$ Similarly, individual year dummies reflected the downward trend in corporate liquidity observed from figure 1: all coefficients in the nineties were negative and those in the eighties were positive. The sharp turnaround in the values of these parameters from 1989 to 1990 motivates the inclusion of a single time dummy variable $D_{\text {nineties }}$ representing a one time downward shift in 1990.

Columns (3) to (6) show that the estimates are qualitatively similar across sectors. The sectoral differences pertain particularly to the total debt sensitivity. Liquidity in manufacturing firms is more sensitive to leverage and liquidity for services firms is less sensitive. In addition, there is no particularly strong size effect in liquidity holdings in manufacturing and the debt maturity structure - short debt - seems to have a somewhat smaller impact. For services firms there is no clear distinction in the level of liquidity in the nineties relative to the eighties as shown by the insignificance of $D_{\text {nineties. }}{ }^{17}$

Additionally, in panel B of table 2 we report tests results for the (non)stationarity of the estimated liquidity target on the one hand and the resulting residual on the other. For this purpose, we distinguish between the long run corporate liquidity target $\hat{y}_{i t}^{g}={\hat{\beta_{n}}}^{\prime} x_{i t}$ and the deviation from the target $\hat{\varepsilon}_{i t}^{g}=\hat{\lambda}_{t}+\hat{\eta}_{i}+\hat{v}_{i t}$ (where hats indicate estimated values). According to this definition, we implicitly assume that the vector $x_{i t}$ captures all relevant information that firms use to set their targets. Firm (time) specific elements in the error term are then interpreted as firm (time) specific impediments to achieve convergence to these targets. For this reason, we label the target defined above as a global target.

We use again the Harris and Tzavalis (1999) technique discussed before. For liquidity targets we do not need to account for unit and time effects. We therefore evaluate the normalized least squares estimator of the autoregressive coefficient $(n)$ in $y_{i t}=\varphi y_{i(t-1)}+\phi_{i t}$ where $y_{i t}=\hat{\beta} x_{i t}$. Again we test $H_{0}: n=1-$ at the $95 \%$ confidence level - versus the alternative $H_{a}: n<1$ for which Harris and Tzavalis (1999) demonstrate that

16 This pattern is the same as that resulting from figure 1. The public utilities sector performed in line with the manufacturing firms in terms of the sector dummies, which motivates its allocation to the manufacturing firms.

17 In addition to the general specification in table 2, the long run effect of liquidity substitutes has been explored by including near liquidity. We find no evidence that this variable impacts on long run liquidity targets. 
$\sqrt{N}(\hat{\varphi}-1)$ weakly converges to $N\left(0, \frac{2}{T(T-1)}\right)$. According to the results in panel B, liquidity targets have a unit root. This holds for the whole sample, as well as for the manufacturing and services sectors separately. To test for the nonstationarity of the residual, we apply the same test as used in table 1, including the possibility of fixed effects and a time trend. According to this test, the residual series are stationary. Hence we conclude that liquidity is cointegrated with liquidity targets so that the use of an error correction framework to characterize corporate liquidity dynamics is justified. ${ }^{18}$

Alternatively, we may assume that the firm's liquidity target includes the estimated firm and time specific effects. Then, the target is defined as $\hat{y}_{i t}^{S}=\hat{\beta_{n}^{\prime}} x_{i t}+\hat{\lambda_{t}}+\hat{\eta_{i}}$, while the deviation from the target is given by $\hat{\varepsilon}_{i t}^{s}=\hat{v}_{i t}$. The firm and time specific elements in the liquidity targets then refer to elements in (precautionary) liquidity demand not captured by the $x_{i t}$. Regarding firm specific elements, we do not control, for instance, for the ownership structure of the firm or the extent to which the firm has access to emergency lines of credit. Especially the part of liquidity targets that is motivated by firm-specific information problems may be opaque, so that the inclusion of the firm specific effects controls for unobserved cross-sectional heterogeneity in that regard. ${ }^{19}$

In the dynamic error-correction specification we will use either the global or specific estimated residual as defined above to capture the deviation from target.

\section{The determination of corporate liquidity dynamics}

For the remainder of this section, we shift our attention from the determination of long run liquidity levels to the short run dynamics of corporate liquidity holdings. The empirical dynamic liquidity regression equation looks as follows:

This is an indirect test on cointegration, disregarding for instance the cointegrating relationships that may exist among the $x_{i t}$. Direct, multivariate tests on cointegration, however, usually require $T 64$ for consistency (eg. Baltagi and Kao, 2000).

19 Unit root tests on the specific target and residual respectively lead to the same conclusion as for their global counterparts: nonstationarity cannot be rejected for the target, while it can for the residual. 


$$
\Delta y_{i t}=\sum_{k=1}^{q} \alpha_{k} \Delta y_{i(t-k)}+\sum_{l=0}^{r} \beta_{l}^{\prime} \Delta x_{i(t-l)}+\gamma \hat{\varepsilon}_{i(t-1)}^{z}+\lambda_{t}^{\prime}+\eta_{i}^{\prime}+v_{i t}^{\prime}
$$

where $y$ again represents the corporate liquidity ratio, () $x$ stands for vectors of explanatory variables and $\hat{\varepsilon}_{i(t-1)}^{z}$ with $z \in\{g, s\}$ indicates that the global or specific target has been imposed. Furthermore, $\Delta y_{i(t-k)}=y_{i(t-k)}-y_{i(t-k-1)}$ (where $k=0$ for the dependent variable) and $\Delta x_{i(t-l)}=x_{i(t-l)}-x_{i(t-l-1)}$. Assuming that $q$ and $r$ have been appropriately determined, $v_{i t}^{\prime} \sim I N\left(0, \sigma_{v^{\prime}}^{2}\right)$ where $I N$ stands for distributed independently normally (cf. Hendry and Ericsson, 1991). Since lagged liquidity enters on the right hand side of the regression equation and we model a firm specific random error component, we have to consider and correct for the correlation between lagged liquidity and the regression error. We use the Arellano and Bond (1991) dynamic panel estimation methodology to compute consistent parameter estimates. ${ }^{20}$ The vector of slope coefficients $\beta_{l}$ captures the direct impact of exogenous short run shocks on liquidity. Time and unit specific random effects are captured by $\lambda_{t}^{\prime}$ and $\eta_{i}^{\prime}$, respectively. Finally, the error correction parameter $\gamma$ - required to be negative for dynamic stability - represents the speed of adjustment towards the long run target.

Table 3 presents the regression results comparing restricted error correction estimates where global and specific targets have been imposed alternately. ${ }^{21}$ These results are presented for all firms together, as well as for manufacturing and services firms separately. In this restricted empirical counterpart of equation (2), the short run dynamics are represented by the inclusion of cash flow and investment only (no lags of changes in liquidity were needed for dynamic validity of the equation) in addition to the gradual reversion to the long run target.

20 In the absence of serial correlation, our assumption regarding the properties of the error term are valid and inference from our estimates is appropriate. Within the Arellano and Bond framework, we test for the absence of second order serial correlation to check our dynamic specification.

Alternatively, we have estimated a non-restricted version of equation (2) where all long run determinants of the level of liquidity are included separately. The implied long run coefficients from an unrestricted estimation of equation (2) are broadly similar to the direct estimates of long run liquidity determinants as presented in table 2. Moreover, the resulting estimates on short run dynamics are very similar to those obtained from the restricted estimation presented in table 3 . 
Table 3

Restricted error correction estimates of corporate liquidity

\begin{tabular}{|c|c|c|c|c|c|c|c|}
\hline \multicolumn{8}{|c|}{ PANEL A $\quad$ ESTIMATION RESULTS $^{1}$} \\
\hline \multirow{2}{*}{\multicolumn{2}{|c|}{ Independent variables ${ }^{2}$}} & (1) & (2) & $(3)$ & $(4)$ & $(5)$ & (6) \\
\hline & & All & All & Man & Man & Ser & Ser \\
\hline \multirow{2}{*}{\multicolumn{2}{|c|}{ Cash flow $_{t}$}} & 0.231 & 0.335 & 0.337 & 0.557 & 0.303 & 0.304 \\
\hline & & $(0.117)$ & $(0.113)$ & $(0.194)$ & $(0.186)$ & $(0.170)$ & $(0.169)$ \\
\hline \multicolumn{2}{|c|}{ Investment $_{t}$} & -1.023 & -0.912 & -1.963 & -1.770 & -0.561 & -0.454 \\
\hline & & $(0.204)$ & $(0.186)$ & $(0.367)$ & $(0.329)$ & $(0.272)$ & $(0.229)$ \\
\hline \multirow{3}{*}{\multicolumn{2}{|c|}{$\begin{array}{l}\text { Deviation from global } \\
\text { target }_{t-1} \\
\text { Deviation from specific }\end{array}$}} & -0.114 & & -0.138 & & -0.122 & \\
\hline & & $(0.014)$ & & $(0.021)$ & & $(0.017)$ & \\
\hline & & & -0.824 & & -0.849 & & -0.875 \\
\hline \multicolumn{2}{|c|}{ target $_{t-1}$} & & $(0.059)$ & & $(0.067)$ & & $(0.090)$ \\
\hline \multicolumn{8}{|c|}{ PANEL B } \\
\hline \multicolumn{2}{|c|}{ Firms } & 473 & 473 & 197 & 197 & 182 & 182 \\
\hline \multicolumn{2}{|c|}{ Observations } & 4257 & 4257 & 1773 & 1773 & 1638 & 1638 \\
\hline \multirow{2}{*}{\multicolumn{2}{|c|}{ Joint significance }} & $\mathrm{P}^{2}(3)=$ & $\mathrm{P}^{2}(3)=$ & $\mathrm{P}^{2}(3)=$ & $\mathrm{P}^{2}(3)=$ & $P^{2}(3)=$ & $\mathrm{P}^{2}(3)=$ \\
\hline & & $102.3^{* *}$ & $230.8^{* *}$ & $81.0^{* *}$ & $230.6^{* *}$ & $63.9^{* *}$ & $94.9^{* *}$ \\
\hline \multirow{2}{*}{\multicolumn{2}{|c|}{ Sargan }} & $P^{2}(16)=$ & $P^{2}(16)=$ & $P^{2}(16)=$ & $P^{2}(16)=$ & $P^{2}(16)=$ & $P^{2}(16)=$ \\
\hline & & 21.2 & 23.8 & 12.9 & 15.3 & 21.0 & 21.9 \\
\hline \multicolumn{2}{|c|}{ SOSC } & -0.816 & 1.331 & 0.596 & 1.209 & $-2.647^{* *}$ & 0.071 \\
\hline \multicolumn{8}{|c|}{$\begin{array}{l}\text { Random effects estimates of ) } \text { Liquidity }_{t} \text {, where } \\
\text { robust to heteroskedasticity (cf. White, 1982) at } \\
\text { sample of firms was used in the estimation, "M } \\
\text { services firms, respectively, are used. }\end{array}$} \\
\hline 2 & \multicolumn{7}{|c|}{$\begin{array}{l}\text { Deviation from [...] } \text { target }_{t-1} \text { is the regression error extracted from the random effects estimates } \\
\text { reported in table } 2 \text {, columns (1) (all firms), (3) (manufacturing firms) and (5) (services firms). Global } \\
\text { and specific targets are defined in the text. All other variables are defined as before. ) denotes the first } \\
\text { difference with respect to time. } \text { Liquidity }_{t-1} \text { is instrumented with its own level lagged another period } \\
\text { (i.e. Liquidity }{ }_{t-2} \text { ). Deviation from [...] } \text { target }_{t-1} \text { is instrumented with its own level lagged another period. } \\
\text { Investment is treated as a potentially endogenous variable and is instrumented with its own level } \\
\text { lagged one period. }\end{array}$} \\
\hline 3 & \multicolumn{7}{|c|}{$\begin{array}{l}\text { Joint significance for all variables in the model is tested with a Wald test. Sargan refers to the Sargan } \\
\text { test for overidentifying restrictions and is also heteroskedasticity-consistent (cf. Arellano and Bond, } \\
\text { 1991). SOSC test for second order autocorrelation and is based on estimates of the residuals in first } \\
\text { differences. Significance at the } 5 \text { and } 1 \text { percent error level is indicated by }{ }^{*} \text { and }{ }^{* *} \text {, respectively. }\end{array}$} \\
\hline
\end{tabular}


The gradual reversion to long run liquidity targets is reflected by the negative impact of deviations from these targets on current liquidity dynamics. Imposing the global targets (columns (1), (3) and (5)) produces a 10 percent rate of convergence per year to the long run target. The speed of adjustment implied by these estimates is quite low. Two explanations of this result are possible. Assuming the long-run targets are measured accurately, the observed speed of adjustment suggests that these targets do not play a very important role in a firm's liquidity management. As a corollary, it suggests that actual liquidity developments over periods of several years may resemble the picture that would emerge under pecking order behaviour. ${ }^{22}$ Alternatively, the targets may be measured inappropriately, for instance because the global target neglects the unspecified part of each firm's target as captured by the firm and time specific random effects. These are included in the specific targets to which we now turn.

Columns (2), (4), and (6) indeed show that the speed of adjustment increases considerably when we use specific liquidity targets. We now observe convergence at a rate of more than 80 percent per year. This holds for both the services and the manufacturing sectors. In comparison with the global target results, these findings stress the importance of micro-data analysis in the analysis of liquidity targets and especially target adjustment, since the error correction effort is likely to be seriously under-estimated when the data is analysed at a higher level of aggregation. Here, the link with many macroeconomic studies of money demand is easily made. There, an implausibly low speed of adjustment is often found as well, see for instance Goldfeld and Sighel (1990). Swamy, Tinsley and Moore (1982) already suggest that aggregation problems may be the cause of these results. ${ }^{23}$

In addition, the dynamic specification allows for an investigation of the importance of flow of funds variables that are advocated by the pecking order theory such as cash flow and investment. We find cash flow to affect the change in liquidity positively. Investment has a negative effect. ${ }^{24}$ Both effects are in line both with buffer stock behaviour in a long-run target

22 Shyam-Sunder and Myers (1999) make a similar point for capital structure adjustment.

23 Part of the firm specific effect may still partly capture the structural inability of the firm to make required adjustments to the target. To that extent, we may mis-measure the target and over-estimate the adjustment speed.

24 We have also considered some extensions to the dynamic liquidity equation. Some (unreported) findings in this regard are that the impact of changes in total debt and changes in near liquidity are not statistically significant. The short run responsiveness of liquidity to changes in the opportunity costs of holding 
framework and with the pecking order line of reasoning. The magnitude of the effect is relatively insensitive to the use of global or specific targets. The significance tends to increase when specific targets are used, providing an additional motive to prefer this specification.

However, the absolute magnitude of the effects is low, indicating that the major part of cash flow is not passively added to liquidity. Neither is investment predominantly financed by internal liquid assets. For instance, in an absolute sense - given an average corporate liquidity ratio of $3.1 \%\left(=\mathrm{e}^{-3.480}\right.$, see table 1$)$ and the parameter estimates in column $(1)-$ we conclude that for every guilder worth of investment spending, holdings of liquid assets are reduced by only about three cents. ${ }^{25}$ Note that manufacturing firms' liquidity holdings are more sensitive to investment expenditures than is the case for services firms. Comparing columns (3) and (5), a guilder increase in investment spending reduces holdings of liquid assets by some 4 cents for manufacturing firms and by only slightly more than 2 cent for services firms (the average liquidity ratio is 2.2 percent for manufacturing firms and 3.4 percent for services firms).

The quantitative effect of a one guilder increase in cash flows is even less. For all firms jointly, the effect is approximately one cent. In absolute terms, the sensitivity of manufacturing firms and services firms is about equal. The higher estimated coefficient for manufacturing firms is approximately offset by the lower average liquidity ratio.

Our liquidity results sharply contrast with the capital structure results obtained by Shyam-Sunder and Myers (1999). They find relatively slow and unimportant target adjustment in combination with an almost one-to-one effect of flow-of-funds variables on changes in net or gross debt. Our results are just the opposite, with substantial target adjustment. The evidence thus suggests that liquidity and debt are far from perfect substitutes and throws doubt on the net debt hypothesis.

liquidity was also examined by adding the change in the lending rate. These changes affected dynamic liquidity negatively, but insignificantly. The same result was found for changes in share prices.

25 The absolute impact of a guilder worth of investment spending on changes in holdings of liquid assets is equal to the estimated parameter on investment multiplied by the exponent of average liquidity. 


\section{Conclusion}

In this paper, we empirically investigate the determinants of corporate liquidity holdings in the Netherlands. We contribute to the current literature in two ways. First, we add to the scarce empirical evidence using a new high-quality data set for a representative sample of large non-financial Dutch firms. An important characteristic of these data is its consistent availability over a period of twelve years. As a consequence, the data allow for a panel approach, combining cross-sectional and time characteristics of corporate liquidity holdings. This relates to the second innovative element in our research: we are able to distinguish both theoretically and empirically between long-run and short-run determinants of corporate liquidity holdings. To this purpose, we hypothesise an error correction framework for the empirical analysis.

Our empirical analysis provides clear evidence for the existence of long run corporate liquidity targets. These long run liquidity targets are important not only in explaining liquidity levels, but also stand out in the explanation of (short run) dynamic liquidity in an error correction framework. In conjunction with target adjustment, we find some evidence of short run liquidity behaviour that appears to be in line with a buffer stock line of reasoning. In particular, a firm's investment expenditures and cash flow have a meaningful impact on its liquidity holdings. These results are observationally equivalent with the pecking order implications regarding corporate liquidity dynamics. However, the absolute size of these effects is modest on average and they do not extend to the long run. Hence we interpret them within our empirical model as short run volatility around a long run liquidity target.

The speed of adjustment towards the targets depends on the exactly what elements we include in the specification of the long run targets. In particular, if unobserved heterogeneity across firms and years is not accounted for in the sensitivity of firms to informational problems - and hence the computation of the targets - we document a 10 rate of convergence to the target. This figure compares well with results obtained from macro-studies of money demand. Alternatively, we take into account that a considerable part of the liquidity decision may result from unobservable firm and time specific considerations. In this case we find an annual rate of convergence to target well in excess of 80 percent, well in excess of the $10 \%$ that is usually obtained in macro-studies. Our results point to aggregation problems in macroeconomic demand for money studies. 
We conclude that the corporate liquidity ratio is an actively managed financial ratio and does not passively adjust to financial decisions taken elsewhere in the firm. Based on long run evidence, a pecking order theory of corporate liquidity holdings must be rejected.

\section{References}

- $\quad$ Arellano, M. and S. R. Bond, "Some Tests of Specification for Panel Data: Monte Carlo Evidence and an Application to Employment Equations," Review of Economic Studies, vol. 58, 1991, pp. 277-297.

- $\quad$ Baltagi, B. H. and C. Kao, "Nonstationary Panels, Cointegration in Panels and Dynamic Panels: A Survey," In: Advances in Econometrics, Volume 15, Nonstationary Panels, Panel Cointegration, and Dynamic Panels, edited by B. D. Baltagi, Elsevier Science, 2000, pp. 7-51.

- $\quad$ Brealey, A. and S. Myers, Principles of Corporate Finance, $5^{\text {th }}$ edition, New York, McGraw Hill Book Co., 1996.

- Calomiris, C. W., Himmelberg, C. P. and P. Wachtel, "Commercial Paper, Corporate Finance and the Business Cycle: A Microeconomic Perspective," National Bureau of Economic Research Working Paper Series, no. 4848, 1994.

- Carr, J. and M. R. Darby, "The Role of Money Supply Shocks in the Short-Run Demand for Money," Journal of Monetary Economics, vol. 8, no. 2, 1981, pp. 183-199.

- Chirinko, R. S. and H. Schaller, "Why Does Liquidity Matter in Investment Equations," Journal of Money, Credit, and Banking, vol. 27, no. 2, 1995, pp. 527-548.

- Diamond, D. W., "Financial Intermediation and Delegated Monitoring," Review of Economic Studies, 1984, pp. 393-414.

- Diamond, D. W., "Debt Maturity Structure and Liquidity Risk," Quarterly Journal of Economics, vol. 56, 1991a, pp. 709-737.

- Diamond, D. W., "Monitoring and Reputation: The Choice Between Bank Loans and Directly Placed Debt,” Journal of Political Economy, vol. 99, 1991b, pp. 689-721.

- $\quad$ Ees, H. van, Garretsen, H., Haan, L. de, and E. Sterken, "Investment and Debt Constraints: Evidence from Dutch Panel Data," in: S. Brakman, H. van Ees and S. K. 
Kuipers (red.), Market Behaviour and Macroeconomic Modelling, Macmillan Press, 1998, pp. 159-179.

- $\quad$ Freixas, X. and J.-C. Rochet, The Microeconomics of Banking, The MIT Press, Cambridge, Massachusetts, 1997.

- Goldfeld, S. M. and D. E. Sichel, "The Demand for Money," in: B. M. Friedman en F. H. Hahn (eds.), Handbook of Monetary Economics, Volume I, North-Holland, Amsterdam, 1990.

- Grossman, S. J. and O. D. Hart, “An Analysis of the Principal-Agent Problem," Econometrica, vol. 51, no. 1, 1983, pp. 7-45.

- Haan, L. de, Financial Behaviour of the Dutch Corporate Sector, Thela Thesis, Amsterdam, 1997.

- $\quad$ Haan, L. de, Koedijk, C. G. and J. E. J. de Vrijer, "De Stijging van het Liquiditeitsbezit in de Jaren Tachtig: Een Enquête onder Nederlandse Bedrijven en Financiële Instellingen,” De Nederlandsche Bank Monetaire Monografieën, vol. 12, 1992.

- $\quad$ Haan, L. de, Koedijk, C. G. and J. E. J. de Vrijer, "Buffer Stock Money and Pecking Order Financing: Results from an Interview Study Among Dutch Firms," De Economist, vol. 142, no. 3, 1994, pp. 287-305.

- $\quad$ Harris, R. D. F. and E. Tzavalis, "Inference for Unit Roots in Dynamic Panels Where the Time Dimension is Fixed," Journal of Econometrics, vol. 91,1999, pp. 201-226.

- $\quad$ Hendry, D. F. and N. R. Ericsson, “An Econometric Analysis of U.K. Money Demand in Monetary Trends in the United States and the United Kingdom by Milton Friedman and Anna J. Schwartz,” American Economic Review, vol. 81, no. 1, 1991, pp. 8-38.

- Holmström, B. and J. Tirole, "Financial Intermediation, Loanable Funds, and the Real Sector," The Quarterly Journal of Economics, vol. 112, no. 3, 1997, pp. 663-691.

- Holmström, B. and J. Tirole, "Private and Public Supply of Liquidity," Journal of Political Economy, vol. 106, no. 1, 1998, pp 1-40.

- Holmström, B. and J. Tirole, "Liquidity and Risk Management," Journal of Money, Credit, and Banking, vol. 32, no. 3, 2000, pp 295-319.

- Hubbard, R. G., "Capital-Market Imperfections and Investment,” Journal of Economic Literature, vol. 36, no. 1, 1998, pp. 198-225. 
- Jensen, M. C., "Agency Costs of Free Cash Flow, Corporate Finance and Takeover," American Economic Review, vol. 75, 1986, pp. 323-329.

- $\quad$ Kim, C.-S., Mauer, D. C. and A. E. Sherman, “The Determinants of Corporate Liquidity: Theory and Evidence," Journal of Financial and Quantitative Analysis, vol. 33, no. 3, 1998, pp. 335-359.

- $\quad$ Kuipers, S. K. and B. Boertje, "On the Causes of the Rise in the Liquidity Ratio in the Netherlands During the Early Eighties," De Economist, vol. 136, no. 1, 1988, pp. 5090.

- $\quad$ Myers, S. C. and N. Majluf, "Corporate Financing and Investment Decisions When Firms Have Information That Investors Do Not Have," Journal of Financial Economics, vol. 13, 1984, pp. 187-221.

- Myers, S. C. and R. G. Rajan, “The Paradox of Liquidity,” The Quarterly Journal of Economics, vol. 63, 1998, pp. 733-771.

- $\quad$ Opler, T., Pinkowitz, L., Stulz, R. and R. Williamson, “The Determinants and Implications of Corporate Cash Holdings," Journal of Financial Economics, vol. 52, 1999, pp. 3-46.

- $\quad$ Saidenberg, M. R. and P. E. Strahan, “Are Banks Still Important for Financing Large Businesses?" Federal Reserve Bank of New York Current Issues in Economics and Finance, vol. 5, no. 12, 1999.

- $\quad$ Shyam-Sunder, L. and S. C. Myers, “Testing Static Tradeoff Against Pecking Order Models of Capital Structure," Journal of Financial Economics, vol. 51, 1999, pp. 219244.

- $\quad$ Swamy, P. A. V. B., Tinsley, P. A. and G. R. Moore, “An Autopsy of a Conventional Macroeconomic Relation: The Case of Money Demand," Special Studies Paper 167, Federal Reserve Board, Washington, DC, 1982.

- Weigand, J. and D. B. Audretsch, "Does Science Make a Difference? Investment, Finance and Corporate Governance in German Industries," Centre for Economic Policy Research (CEPR) Working Paper, no. 2056, 1999.

- White, H., "Instrumental Variables Regression with Independent Observations," Econometrica, vol. 50, 1982, pp. 483-499. 